
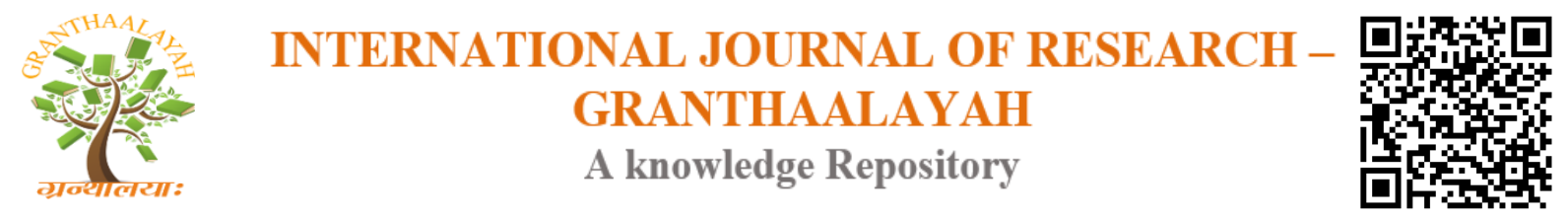

Social

\title{
GENDER DISPARITY TOWARDS STUDENTS ENROLLMENT IN TECHNICAL EDUCATION IN RIVERS STATE: CAUSES, EFFECTS AND STRATEGIES
}

\author{
Dr. Dokubo, Isaac Nwojiewho ${ }^{1}$, Deebom, Mtormabari Tambari ${ }^{2}$ \\ ${ }^{1}$ Department of Vocational and Technology Education, Rivers State University, Port Harcourt \\ ${ }^{2}$ Department of Vocational and Technology Education, Rivers State University, Port Harcourt
}

\begin{abstract}
This study examined the gender disparity towards students' enrollment in technical education in Rivers State. A sample of 403 students (362 Male and 41 Female) was selected through simple random sampling technique from Rivers State University (RIVSU) and Ignatius Ajuru University of Education (IAUOE), Port Harcourt from the Department of Technical Education. Three research questions were posed to guide the study and two Null hypotheses were formulated and tested at 0.05 level of significant. Structured questionnaire was used to collect data. A reliability coefficient of 0.83 was established through Cronbach Alpha using test-retest method. Data were analyzed using mean and standard deviation for research questions and hypotheses were tested using the independent sample t-test. The study revealed amongst others that poverty, preference of male child, cultural and religious beliefs were causes of female folks low enrollment into technical education programmes in Rivers State. Based on the findings of the study, it was recommended amongst others that; allowances, scholarships, employment opportunities should be given to female students in order to enhance their enrolments into technical education programmmes in Rivers State.
\end{abstract}

Keywords: Disparity; Enrollment; Gender; Technical Education; Cultural and Religious Beliefs.

Cite This Article: Dr. Dokubo, Isaac Nwojiewho, and Deebom, Mtormabari Tambari. (2017). "GENDER DISPARITY TOWARDS STUDENTS ENROLLMENT IN TECHNICAL EDUCATION IN RIVERS STATE: CAUSES, EFFECTS AND STRATEGIES." International Journal of Research - Granthaalayah, 5(10), 1-10.

\section{Introduction}

Education is a right to which every child (male and female) must have access to because it is the most potent and valuable instrument for cultural, political and socioeconomic development. It is a vital tool for national development and integration (Dokubo, 2015). Education also as a normative enterprise generates issues in the society particularly on gender supremacy. Gender issues constitute an educational concern that has given rise to a lot of debates, conflicts etc in almost all aspects of human endeavors. Gender issues hinge on either gender parity or 
disparity. Gender according to Afu, Gbobo, Udofia and Itakure (2017) refers to the social attributes and opportunities associated with being male or female and the relationships between women and men and girls and boys, as well as the relations between women and those between men. These attributes, opportunities and relationships are socially constructed and are learned through socialization processes. In most societies there are differences and inequalities between women and men in responsibilities assigned, activities undertaken, access to and control over resources, as well as decision-making opportunities. Gender equality refers to the equal rights, responsibilities and opportunities of women and men and girls and boys...equality does not mean that women and men will become the same but that women's and men's rights, responsibilities and opportunities will not depend on whether they are born male or female (United Nations, 2003). Gender parity or equality means a situation where male and female enjoys the same opportunities, rights, outcomes, obligations in all spheres of human endeavours. On the contrary, gender disparity or inequality occurs when one gender (male or female) dominates another in a particular sector (education), training etc. In order to bridge the gap of gender disparity, the movement towards free Universal Primary Education (UPE) where every child has right for education in the nation in 1976 was introduced which have metamorphosed to the current Universal Basic Education (UBE) since 2000 has helped increase access to education for all social classes in Nigeria in terms of gender at primary, secondary level. But shockingly at the tertiary level and especially in technical education, the disparity level increases. Gender disparity is a common phenomenon in African education institution. While a number of efforts have been under way to rectify gender disparity, much still remain to be done across all educational sectors. There seem to be a natural gender role distinction all over the world, which has created gap in opportunities between men and women. This identified gap has constituted what is generally regarded as gender inequality among gender advocates. Despite this free education in Nigeria, there still exists some gender dominance syndrome which has created a disparity in the educational system especially in technical courses. The disparity is noticeable in gender enrolment at all levels and types of education, as well as across various disciplines and programmes, especially at the tertiary level.

In spite of the general commitment to the principle of non - discrimination as enshrined in section two of the 1999 Constitution of the Federal Republic of Nigeria, males and females are not given equal opportunities to advance socially, physically, educationally, politically and economically. Evidences abound that several negative aspects of gender relations, such as gender-based divisions of labour, disparities between males and females access to power and resources, gender biases in rights and entitlements, remain pervasive in Nigeria (National Gender Policy, 2006). The fact however remains that girl's education in colonial West Africa did not make rapid progress as that of the boys. According to UNICEF (2011) the gap between the male and female literacy rates is not just about men and women and the educational opportunities provided for them, but it is also a statement about the society's development, and its capacity and willingness to provide such opportunities. In Nigeria today, the Federal Government has stipulated in the National Policy on Education that every Nigerian child (male and female) shall have right to equal educational opportunities irrespective of any real or imagined disabilities, distinctions or dichotomies such as gender, ethnic group, religion or social status (Federal Republic of Nigeria (FRN, 2013). It is unfortunate that despite all the appreciable efforts of the government to achieve equalization of educational opportunities (educational parity), there still exist noticeable disparities in educational attainment in terms of 
gender in technical education in tertiary institutions in Rivers State. This is a current educational issue of no mean order. Gender issues have long been identified as one of the most pressing hindrances in the Nigerian Education System and the world at large. This is more amplified and recurring in technical education. However, the National Policy on Education (FRN, 2013) gives an equal opportunity document which is devoid of gender bias specifically in technical and vocational courses for skill development. Dokubo, (2010) also indicates that the goals of technical and vocational education are oriented towards producing skilled manpower and no distinction is made between the sexes in skills acquisition. Technical Education is a training geared towards the development of the individual both mentally, physically, technically and emotional. It is an education that involves both males and females, hence gender unbiased. Consequently, Technical and Vocational Education (TVE) is used as a comprehensive term referring to those aspects of the educational process involving in addition to general education, the study of technologies, related sciences, and the acquisition of practical skills, attitudes understanding and knowledge relating to occupations in various sectors of economic and social life (UNESCO, 2002). According to Ibeneme (2007), Nigeria does not seem to accord technical and vocational education (TVE) the attention it deserves. Surprisingly, gender disparity in technical education in Nigeria has been an issue of serious concern to educators, women themselves and other stakeholders. Gender disparity in technical education in Nigeria has been an issue of serious concern to educators, women themselves and other stakeholders. Usoro, Usoro, Ibritam and Udofia (2009) identified causes of gender disparity in the Nigerian technical colleges to include: sex factor, parental interest, teachers, government and nature of technical education, female preference for some subjects and not others, traditional prejudice against education of women in Nigeria and Africa. In Ghana, Swaziland, Zambia and other African nations, males dominate over female counterparts in secondary and tertiary institutions in technical related courses as reported by Wheldon and Smith cited in Hogan, Akpan and Udeme (2013). Causes cited include; sex factor, discrimination in admissions process, nature of technical education subjects and females' subject preference.

The effect of educational disparity among male and female in technical education is glaring because despite the introduction of the Universal Basic Education in 2000, the female gender is still lagging behind in education generally but especially in technical education and this has much implication in the social-economic status of the females in the nation. If drastic measures are not taken, tomorrows' education in Nigeria may be all male affairs as the females dominate the markets, the farms and the homes to make more babies and increase poverty in the land. According to The National Population Census (2006), figures shows that Nigeria as a country have a sex composition that is almost fifty fifty (50:50) for males and females, but the country's' educational pendulum bob swings to the male gender. According to Foluke (2010), these inequalities have condemned thousands of children to a life without quality education, to a life of missed opportunities and aborted dreams. Foluke suggested that, to eliminate gender disparity and reduce the gender gap in education, there is the need for a change in people's mindsets especially among the female counterpart, an education system and structures that will take care of the constraints bedeviling it. 


\subsection{Statement of the Problem}

In our African society, the education of women did not receive significant attention and this led to the second class status assigned to women in society. Women are relegated to mere agents of domestic engagements at home, with considerable reproductive roles. This apathy arising from gender disparity has also affected education in Nigeria particularly in technical education programmes in tertiary institutions in Rivers State. As a result, the male folks have dominated Nigerian schools from the primary to tertiary level more especially in technical education and allied disciplines. The National Population Census (2006) figures shows that Nigeria as a country has a sex composition that is almost fifty-fifty (50:50) for males and females, but the educational pendulum bob tends to swings to the male gender only. Why? In attempt to provide answer to this question prompted the researchers to investigate causes and effect of such gender disparity in technical education enrollments in Rivers State tertiary institutions.

\subsection{Purpose of the Study}

The purpose of the study is to investigate causes of gender disparity towards students' enrollment in technical education in Rivers State. Objectively, the study seeks to;

i. Examine the causes of low female enrollment in technical education programme in Rivers State tertiary institutions.

ii. Describe the effect of female low enrollment in technical education programme in Rivers State tertiary institutions.

iii. Outline the strategies to improve female enrollment in technical education programme in Rivers State tertiary institutions.

\subsection{Research Questions}

The following research questions were answer to guide this study;

i. What are the causes of female low enrollment in technical education programmes in Rivers State tertiary institutions?

ii. What are the effects of female low enrollment in technical education programmes in Rivers State tertiary institutions?

iii. How can low female participation in technical education programmes in Rivers State tertiary institutions be improved?

\subsection{Hypotheses}

The following null hypotheses were formulated and tested at 0.05 level of significance.

i. There is no significant difference in the mean scores of male and female students on the causes of low female enrollment in technical education programmes in Rivers State tertiary institutions.

ii. There is no significant difference in the mean scores of male and female students on improving strategies in low female enrollment in technical education programmes in Rivers State tertiary institutions. 


\section{Materials and Methods}

This study adopted the descriptive survey research design. The study was carried out in the Department of Vocational/Technology Education, Rivers State University (RSU) and Ignatius Ajuru University of Education (IAUOE), Port Harcourt. The Population of the study consists of 469 regular undergraduate students of Technical Education from the schools. A sample of 403 (362 Male and 41 Female) students was selected through simple random sampling technique. This represent represents $86 \%$ of the population which was used for the study. The instrument for data collection for the study was a self-constructed questionnaire titled "Gender Disparity on Students Enrollment in Technical Education Programmes Questionnaire" (GDSETEPQ). The instrument was subdivided into various sections $A$ to $C$ based on the research questions. GDSETEPQ was designed and pattern after Likert-5-point rating scale of Strongly Agree (SA), Agree (A), Undecided (UD), Disagree (D) and Strongly Disagree (SD) with a corresponding numerical values of 5, 4, 3, 2 and 1 respectively. The questionnaire was faced validated by two experts in Technical Education Department from Rivers State University, Port Harcourt for relevancy, appropriateness and corrections were made before administration.

For the determination of the instrument, copies of GDSETEPG were administered to 13 male and 7 female students who were not part of the sample. The Cronbach Alpha was used to ascertain the reliability using test-retest method which yields 0.83 . This result implies that the instrument was reliable. The administration of the instrument was done by the researchers with the help of two students who were trained as research assistants. A total of 403 copies of GDSETEPG were administered while 392 was successfully retrieved and used for the analysis. In analyzing the research questions, descriptive statistic of mean with standard deviation were used. In answering the research questions, any item less than 3.00 was rejected while a mean score that is equal to or greater than 3.00 were accepted. In testing the hypotheses, the independent t-Test was used. If the calculated value of $t$ (tcal) is less than or equal to the critical value of $t$ (tcrit), the hypothesis is accepted but if the calculated value of $t$ (tcal) is greater than the critical value of $\mathrm{t}$ (tcrit), the hypothesis is rejected.

\section{Results and Discussion of Findings}

The results of this study were presented in order of the research questions and hypotheses.

Research Question 1: what are the causes of female low enrollment in technical education programmes in Rivers State tertiary institutions?

Table 1: Mean Scores of Respondents on Causes of Low Female Enrollment in Technical Education Programmes in Rivers State Tertiary Institutions

\begin{tabular}{llllllll}
\hline S/N & & \multicolumn{2}{c}{ Males (362) } & \multicolumn{2}{c}{ Females (41) } & & \\
& Variables & X & SD & X & SD & GM & Remarks \\
\hline 1 & $\begin{array}{l}\text { Lack of family and peers support } \\
\text { Girls' education were considered }\end{array}$ & 4.01 & 1.03 & 4.62 & 0.50 & 4.32 & Accepted \\
2 & $\begin{array}{l}\text { waste due to their future marriage } \\
\text { Technical field requires physical }\end{array}$ & 3.76 & 1.30 & 3.81 & 0.82 & 3.73 & Accepted \\
& \begin{tabular}{l} 
strength \\
\hline
\end{tabular}
\end{tabular}




\begin{tabular}{|c|c|c|c|c|c|c|c|}
\hline 4 & Girls are seen as home-makers only & 3.23 & 0.75 & 3.60 & 0.79 & 3.42 & Accepted \\
\hline 5 & poverty & 3.59 & 0.64 & 4.31 & 0.81 & 3.95 & Accepted \\
\hline 6 & Religious Beliefs & 3.40 & 0.66 & 4.46 & 0.55 & 3.93 & Accepted \\
\hline 7 & $\begin{array}{l}\text { Societal preference for male child } \\
\text { training }\end{array}$ & 4.30 & 0.71 & 3.76 & 1.06 & 4.03 & Accepted \\
\hline 8 & $\begin{array}{l}\text { The greasy and oily nature of technical } \\
\text { courses }\end{array}$ & 3.98 & 0.87 & 3.28 & 0.64 & 3.63 & Accepted \\
\hline 9 & Fear of engineering courses & 3.64 & 0.76 & 3.77 & 0.61 & 3.71 & Accepted \\
\hline 10 & Early marriage & 3.70 & 1.20 & 4.07 & 1.09 & 3.89 & Accepted \\
\hline 11 & Parents perception and values & 3.19 & 0.53 & 3.60 & 0.82 & 3.40 & Accepted \\
\hline 12 & Cultural beliefs & 3.77 & 1.03 & 4.31 & 0.71 & 4.04 & Accepted \\
\hline
\end{tabular}

Source: Authors' Field Survey; 2017 SD (Standard Deviation) GM (Grand Mean)

Table 1 showed that the listed statement were all accepted by the respondents as causes of female low enrollment into Technical Education programmes in Rivers State tertiary institutions. The result shows that poverty, cultural beliefs and parent's preference of male over females were some of the causes affecting female's enrollment into technical education programmes in Rivers State tertiary institutions. This result is in line with the findings of Olugbile (2010) who observed that gender gap in higher education in Nigeria could be as a result of economic costs, social traditions, and religious and cultural beliefs limit girls' educational opportunities, while the boys are most times encouraged attending school. Early marriage of the female child and social practices has also been identified from the findings of this study as a major cause of gender disparity in education. This result is in line with Nnachi (2010) who aver that northern females are sheltered and groomed for early marriage which limits their chances of being educated. Also, the study agree with Maluwa-Banda and Kholowa as cited (in Afu, Gbobo, Ukofia \& Itakure, 2017) reports that socio-economic factors include family poverty, direct cost of schooling. Sociocultural factors include pregnancies and early marriages, initiation practices, parental attitudes and aspirations for children, household chores, puberty-related issues, death in the family, and caring for the sick parents or relatives.

Research Question 2: what are the effects of female low enrollment in technical education programmes in Rivers State tertiary institutions?

Table 2: Mean Scores of Respondents on the Effect of Female Low Enrollment in Technical Education Programmes in Rivers State Tertiary Institutions

\begin{tabular}{|c|c|c|c|c|c|c|c|}
\hline \multirow[t]{2}{*}{$\mathbf{S} / \mathbf{N}$} & \multirow[t]{2}{*}{ Variable } & \multicolumn{2}{|c|}{ Males (362) } & \multicolumn{2}{|c|}{ Females (41) } & \multirow[b]{2}{*}{ GM } & \multirow[b]{2}{*}{ Remark } \\
\hline & & $\mathbf{X}$ & SD & $\mathbf{X}$ & SD & & \\
\hline 13 & It reduces women level in labour market & 3.33 & 1.10 & 3.24 & 0.81 & 3.29 & Accepted \\
\hline 14 & $\begin{array}{l}\text { It makes the woman over depending on } \\
\text { the man }\end{array}$ & 3.52 & 0.61 & 3.67 & 0.92 & 3.60 & Accepted \\
\hline 15 & It increases poverty & 4.21 & 0.71 & 3.81 & 1.11 & 4.01 & Accepted \\
\hline 16 & Increase in sex commercial workers & 3.96 & 0.87 & 3.22 & 1.08 & 3.59 & Accepted \\
\hline 17 & High level of illiteracy & 3.59 & 1.14 & 4.09 & 0.61 & 3.84 & Accepted \\
\hline 18 & Increase in crime & 4.04 & 1.07 & 3.98 & 0.82 & 4.01 & Accepted \\
\hline 19 & High rate of unwanted pregnancy & 3.42 & 0.91 & 3.19 & 1.04 & 3.31 & Accepted \\
\hline
\end{tabular}




\begin{tabular}{llllllll}
\hline 20 & $\begin{array}{l}\text { It makes the girl child a corporate } \\
\text { beggar }\end{array}$ & 3.06 & 0.71 & 3.60 & 0.73 & 3.33 & Accepted \\
21 & $\begin{array}{l}\text { It causes women under-representation } \\
\text { in other sector }\end{array}$ & 3.70 & 1.20 & 4.23 & 0.94 & 4.00 & Accepted \\
\hline
\end{tabular}

Source: Authors' Field Survey; 2017 SD (Standard Deviation) GM (Grand Mean)

Table 2 identified some of the effect of female low participation in technical education programmes in Rivers State tertiary institutions. The study found that increase in crime, increase in prostitution, females becoming corporate beggars as its effect. This implies that female low enrollment in technical education will reduces women level of productivity in the labour market. This result is line with Okafor and Arinze (2014) who stressed that women's education will increase the level of women in the labour workforce of the nation and also increases productivity and self-employment in the informal sector especially among rural women in relation to production incentives, marketing facilities, distribution of seeds and fertilizers and rural extension programmes.

Research Question 3: How can low female participation in technical education programmes in Rivers State tertiary institutions be improved?

Table 3: Mean Scores of Respondents on Improvement Strategies for Low Female Enrollment in Technical Education Programmes in Rivers State Tertiary Institutions

\begin{tabular}{|c|c|c|c|c|c|c|c|}
\hline \multirow[t]{2}{*}{$\mathbf{S} / \mathbf{N}$} & \multirow[t]{2}{*}{ Variable } & \multicolumn{2}{|c|}{ Males (362) } & \multicolumn{3}{|c|}{ Females (41) } & \multirow[b]{2}{*}{ Remark } \\
\hline & & $\mathbf{X}$ & SD & $\mathbf{X}$ & SD & GM & \\
\hline 22 & $\begin{array}{l}\text { Admission cut-off point for girls } \\
\text { should be reduce }\end{array}$ & 4.06 & 0.63 & 4.21 & 0.80 & 4.13 & Accepted \\
\hline 23 & $\begin{array}{l}\text { Given of scholarship to females in } \\
\text { technical education disciplines }\end{array}$ & 4.31 & 0.94 & 3.98 & 0.89 & 4.15 & Accepted \\
\hline 24 & $\begin{array}{l}\text { Absorbing more females as lecturers } \\
\text { after graduation }\end{array}$ & 3.73 & 1.03 & 3.30 & 0.61 & 3.52 & Accepted \\
\hline 25 & $\begin{array}{l}\text { Proper guidance and counseling for } \\
\text { female students }\end{array}$ & 3.76 & 0.81 & 3.75 & 1.04 & 3.76 & Accepted \\
\hline 26 & $\begin{array}{l}\text { Provision of employment } \\
\text { opportunities for female graduates of } \\
\text { technical education }\end{array}$ & 3.88 & 1.04 & 3.96 & 0.87 & 3.92 & Accepted \\
\hline 27 & $\begin{array}{l}\text { Building a self-confident in the female } \\
\text { students through sensitization }\end{array}$ & 3.97 & 1.11 & 3.14 & 0.56 & 3.56 & Accepted \\
\hline 28 & $\begin{array}{l}\text { The introduction of technical related } \\
\text { courses at the primary levels }\end{array}$ & 4.22 & 0.58 & 3.59 & 0.62 & 3.91 & Accepted \\
\hline 29 & $\begin{array}{l}\text { Given of allowances to female } \\
\text { students }\end{array}$ & 4.41 & 0.81 & 3.60 & 0.72 & 4.01 & Accepted \\
\hline
\end{tabular}

Source: Authors' Field Survey; 2017 SD (Standard Deviation) GM (Grand Mean)

Table 3 showed that the listed statement were all accepted by the respondents as strategies to improve female low enrollment into Technical Education programmes in Rivers State tertiary institutions. The result shows that given of allowances to female students, absorbing more females as lecturers after graduation, given of scholarships to female students are some of the 
strategies to improve female's enrollment into technical education programmes in Rivers State tertiary institutions. This finding is in collaboration with Ayomike (2014) who opined that scholarship to TVET students will increase female low participation in TVET.

\section{Statistical Test of Hypotheses}

$\mathbf{H}_{\mathbf{O 1}}$ : There is no significant difference in the mean scores of male and female students on the causes of low female enrollment in technical education programmes in Rivers State tertiary institutions.

Table 4: t-Test Analysis on Causes of Female Low Enrollment in Technical Education

\begin{tabular}{llllllll}
\hline Group & $\mathbf{N}$ & $\mathbf{X}$ & SD & df & tcal & tcrit & Remark \\
\hline Males & 362 & 3.69 & 0.88 & & & & \\
Females & 41 & 3.96 & 0.79 & & & & \\
\end{tabular}

Source: Authors' Result; 2017 Accept Ho if tcal $\leq$ tcrit, else Reject

Since the calculated value of $\mathrm{t}$ (tcal) is greater than the critical value of $\mathrm{t}$ (tcrit), the null hypothesis that there is no significant difference in the mean scores of male and female students on the causes of low female enrollment in technical education programmes in Rivers State tertiary institutions was accepted.

$\mathbf{H}_{\text {O2: }}$ : There is no significant difference in the mean scores of male and female students on improving strategies in low female enrollment in technical education programmes in Rivers State tertiary institutions.

Table 5: t-Test Analysis on Strategies to Improve Female Low Enrollment in Technical Education

\begin{tabular}{llllllll}
\hline Group & $\mathbf{N}$ & $\mathbf{X}$ & SD & df & tcal & tcrit & Remark \\
\hline Males & 362 & 4.04 & 0.86 & & & & \\
& & & & 401 & 2.72 & 1.960 & Rejected \\
Females & 41 & 3.69 & 0.76 & & & & \\
\hline
\end{tabular}

Source: Authors' Result; 2017 Accept Ho if tcal $\leq$ tcrit, else Reject

Since the calculated value of $\mathrm{t}(\mathrm{t}-\mathrm{cal})$ is greater than the critical value of $\mathrm{t}$ (tcrit), the null hypothesis that there is no significant difference in the mean scores of male and female students on the causes of low female enrollment in technical education programmes in Rivers State tertiary institutions was accepted.

\section{Conclusion}

From the findings of the study, it can be concluded that gender disparity among male and female students in technical education in Rivers State tertiary institutions has been identified to have some effects which are caused by certain factors. Its effects are female over dependent on the male, high level of illiteracy, increase in prostitution among the female folks while its cause were 
cultural beliefs, societal preference to male child, etc. The strategies in bridging this gap have been provided in this study such as provision of scholarships, allowances and employment opportunities for female graduates. These will help to reduce gender disparity in students' enrollment in technical education programmes in Rivers State tertiary institutions.

\section{Recommendations}

Based on the findings of this study, the following recommendations were made as follows:

1) Payment of study allowance for female Technical Education students.

2) Inclusion of technical related courses at the primary education level.

3) Employment opportunities for more female Technical Education lecturers.

4) Reduction of admission standards for female students into Technical Education.

\section{References}

[1] Afu, M . O., Gbobo, V. F., Ukofia, I. F. \& Itakure, Z. S. ( 2017). Effect of Gender Disparity in the Enrolment of Students in Public Secondary Schools in Gwagwalada Area Council, Federal Capital Territory, Abuja, Nigeria. International Journal of Scientific Research in Education, 10 (2), 201-211.

[2] Ayomike, C. S. (2014). Factors Affecting Female Participation in Technical Education Programme: A Study of Delta State University, Abraka. Journal of Education and Human Development, 3 (3), 227-240.

[3] Dokubo, I.N. (2010). Vocational educational programmes and empowerment of rural adults In Rivers East Senatorial District, Rivers State. An unpublished Ph.D dissertation, University of Calabar, Cross Rivers State.

[4] Dokubo, I.N (2015). The effects of learning environments on vocational and technical education programmes in Rivers State, Ngeria. International journal of humanities, social sciences and education. 2, (9) pp.182-18

[5] Federal Ministry of Women Affairs and Social Development (2006). National Gender Policy: Federal Republic of Nigeria, Amana Printing Ltd, Abuja.

[6] Federal Republic of Nigeria (2013): National Policy on Education 13th Ed. Lagos: NERDC Press.

[7] Foluke, F. (2010). Gender Inequality in Education: Implications for National Development, International Educational Research Journals, 4 (2), 106-117.

[8] Hogan, U., Akpan, A. A., \& Udeme, S. U. (2013). Gender Issues in Technical Education, Problems and Prospects: Technical Education Programme in Akwa Ibom State College of Education in Perspective. African Education Indices, 7 (1), 1-14.

[9] Ibeneme, O. T. (2007). Vocational Technical Education: Nigerian's Imperative for Achieving the First Millennium Development Goal Initiative. Journal of Vocational and Adult Education. 6 (1), 54-61.

[10] National Population Commission (2006). National Census Report. Lagos: NPC.

[11] Nnachi, R.O. (2010). Sex Education in Nigeria School: A Psychological Position. Owerri: Barloz Publishers.

[12] Okafor, V. E \& Arinze, F.O. (2012). Gender Accessibility and Equality in Education: The Implication to Manpower Development in Nigeria. An International Multidisciplinary Journal, Ethiopia, 6 (3), 284-292.

[13] UNICEF (2011). Children and women rights in Nigeria. A wake up call (Situation Assessment and Analysis). Abuja, Nigeria: National Planning Commission and UNICEF.

[14] United Nations (2003). What is gender? Retreived from www.who.int/whatisgender/en. 
[15] United Nations Educational, Scientific and Cultural Organization (UNESCO) (2002). Recommendations Concerning Technical and Vocational Education. Paris: World Education Report.

[16] Usoro, H. S. U., Usoro, M. Ibritam, K. \& Udofia, W. U. (2009). Causes of Male Students' Dominance over Female Counterparts in the Nigerian Technical Colleges: A Case Study of Abia State Technical Colleges. Journal of National Association of Teachers of Technology, 7 (1), 43 49.

\footnotetext{
*Corresponding author.

E-mail address: dokusii@ yahoo.com/tambari.deebom@ ust.edu.ng
} 